\title{
Investigating foraging utilization distribution of female New Zealand sea lions, Auckland Islands
}

\author{
B. Louise Chilvers · Jacinda M. Amey • \\ Luis A. Huckstadt • Dan P. Costa
}

Received: 28 April 2010/Revised: 17 October 2010/Accepted: 18 October 2010/Published online: 3 December 2010

(C) The Author(s) 2010. This article is published with open access at Springerlink.com

\begin{abstract}
Detrimental interactions between marine mammals and fisheries are increasing worldwide. The ability to manage these interactions requires the knowledge of where and how interactions occur and the effects they have on species. Many pinnipeds are central place foraging colonial breeders who are restricted in foraging range during breeding. Here, we use a utilization distribution approach to examine the foraging habitats of lactating New Zealand (NZ) sea lions (Phocarctos hookeri) from Dundas and Enderby Islands, Auckland Islands. Annually, the NZ sea lions which breed on these two islands produce $83 \%$ of this Nationally Critical species' pups. Satellite transmitters were attached to 55 females during 2001-2007. Data showed that NZ sea lions utilize the entire Auckland Island shelf with partial habitat partitioning between females from the two breeding islands. This habitat partitioning results in differing degrees of overlap with fisheries and therefore possible differing fishery-related impacts on breeding areas.
\end{abstract}

\footnotetext{
B. Louise Chilvers ( $\square)$

Department of Conservation, Aquatic and Threats Unit, P.O. Box 10420, Wellington 6143, New Zealand e-mail: 1chilvers@doc.govt.nz

J. M. Amey

802 Waikouiti/Palmerston Rd, RD 1, Palmerston, Otago 9481, New Zealand

\section{A. Huckstadt}

Ocean Sciences Department, University of California Santa

Cruz, Santa Cruz, CA 95060, USA

D. P. Costa

Department of Ecology and Evolutionary Biology,

University of California, Santa Cruz, CA 95060, USA
}

Keywords Phocarctos hookeri - Satellite tracking · Marine protection - Foraging habitat

\section{Introduction}

Interactions between marine mammals and fisheries are increasing worldwide and can have adverse effects for the fisheries, the marine mammals or both (Twiss and Reeves 1999). The ability to manage these interactions requires the knowledge of where and how interactions occur and the effects of the interactions. One of the first steps to understanding where interactions occur requires the understanding of animals' foraging behaviours and locations. The foraging behaviours of marine predators are determined by the interaction between the abundance and distribution of prey, and the energetic requirements, geographic location and physiological limits of the animal (Hunt et al. 1990; Costa 1991a, b; 1993; Robertson 1994; Weimerskirch 1998). For mammal predators, lactation is the most energydemanding period for a female. Therefore, during this time, they must optimize their foraging behaviour to maximize energy intake to rear their offspring successfully (Gittleman and Thompson 1988; Arnould 1997; Trillmich and Weissing 2006; Costa 2007). Pinnipeds (seals and sea lions) are marine mammal predators who are often central place foraging colonial breeders which restrict their foraging range during breeding and can heighten impacts with fisheries activities as they have no alternative foraging locations.

The New Zealand (NZ) sea lion, Phocarctos hookeri, is one of the world's rarest pinnipeds with a restricted population range, classified as "Nationally Critical" under the New Zealand threat classification system (Baker et al. 2010). NZ sea lions breed on Auckland and Campbell Islands in the New Zealand subantarctic between latitudes 
of $48^{\circ} \mathrm{S}$ and $53^{\circ} \mathrm{S}$ (Gales and Mattlin 1997; Chilvers et al. 2007). Their population size is one of the smallest reported for an otariid (9,880, Geschke and Chilvers 2009), and the species' pup production has shown a $50 \%$ decline in the last 10 years (Campbell et al. 2006; Chilvers et al. 2007; Geschke and Chilvers 2009).

Over the past decade, the interaction between NZ sea lions and the arrow squid (Nototodarus sloanii) trawl fishery, which operates on the Auckland Island shelf between February and May each year, has been investigated (Baird 1996; Gales and Mattlin 1997; Uozumi 1998; Costa and Gales 2000; Wilkinson et al. 2003; Chilvers et al. 2005, 2006; Chilvers 2008a). Squid constitute a seasonally, temporally and individually variable proportion of a sea lion's diet (Childerhouse et al. 2001; Meynier et al. 2009). However, because some sea lions forage on and trawlers target the same prey near the main breeding site, up to 140 or greater than $1 \%$ of the entire estimated population of sea lions are estimated to be captured and killed in squid trawl nets during each breeding season (Baird 1996; Wilkinson et al. 2003; Campbell et al. 2006; Chilvers 2008a).

Currently, the arrow squid trawl fishery is regulated to reduce the sea lion/fisheries interactions by setting limits on the number of sea lions that the trawl fishery may kill, as bycatch, within the fishery management area surrounding the Auckland Islands. Once this limit is exceeded, the fishery area can be closed for the season. This is referred to as the Fishery-Related Mortality Limit (FRML). A FRML has been utilized for the last 12 years with fisheries being officially closed five times, attempted to be closed but overturned by court cases three times and had the fishing industry voluntarily withdrawal twice (Chilvers 2008a). However, within this time, the species' pup production has dropped by $50 \%$, suggesting that this management is not providing sufficient protection for this threatened marine mammal. An alternative management option would be to identify and then to implement a marine protected area within the essential foraging areas of breeding NZ sea lions that excludes the trawl fishery, but allows squid jigging, which has been shown to result in minimal pinniped bycatch; (Arnould et al. 2003; Chilvers 2008a). Therefore, a better understanding of where NZ sea lions forage and their vulnerability to fisheries activities is essential.

The objective of this research was to examine the foraging locations of lactating NZ sea lions breeding on the two subantarctic islands, Dundas and Enderby using a colony area utilization approach. These islands lie only $8 \mathrm{~km}$ apart in the Auckland Islands group (Fig. 1). Females on Dundas Island produce 1,100-1,500 pups or $64 \%$ of all pups born each season, whereas females from Sandy Bay, Enderby Island, produce 300-400 pups each year or $19 \%$ of the total annual pup production (Chilvers et al. 2007).

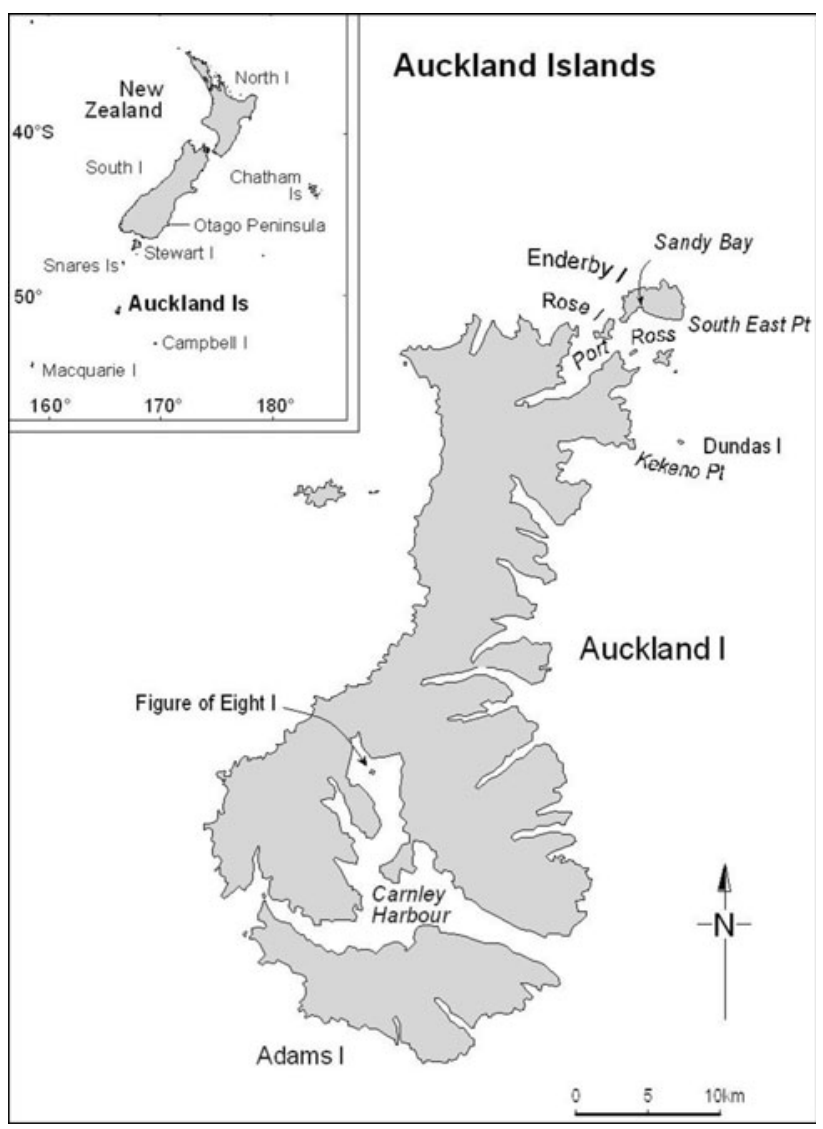

Fig. 1 Auckland Islands showing the main breeding islands for NZ sea lions: Enderby island; Dundas island; and Figure of Eight islands, Carnley Harbour. Inset New Zealand's subantarctic area

These two islands are considered one breeding area due to the within-breeding season movements and mating of adult males at the two islands (Robertson et al. 2006). Females do however show high philopatry and breeding site fidelity to their breeding island (Chilvers and Wilkinson 2008). The aim of this research was to identify where lactating females from these two breeding locations forage and determine whether they utilize separate foraging areas and the extent of these areas' overlap with fisheries activities. The foraging areas of 26 females from Enderby Island have been previously investigated (Chilvers et al. 2005; Chilvers and Wilkinson 2009). Female NZ sea lions from Enderby Island show extreme site fidelity to foraging locations both within and between years (Chilvers 2008b). Here, we present the foraging areas of 29 females from Dundas Island to allow comparisons between the lactating females from the two islands. By gaining an understanding of the foraging habitat and partitioning of resources between the breeding islands, we will be able to identify where breeding females' foraging areas and the activities of the trawl fishery overlap and the potential management implications for this overlap. 


\section{Materials and methods}

Study site, captures and instrumentation

Satellite data were collected from 29 lactating NZ sea lions from Dundas Island, Auckland Islands $\left(50^{\circ} 35^{\prime} \mathrm{S}, 166^{\circ} 19^{\prime} \mathrm{E}\right.$; Fig. 1), over three breeding seasons (December to February) from 2005 to 2007 . These data were compared with data collected from Sandy Bay, Enderby Island $\left(50^{\circ} 30^{\prime} \mathrm{S}\right.$, $166^{\circ} 17^{\prime}$ E; Fig. 1), over four breeding seasons from 2001 to 2004 (Chilvers et al. 2005).

Due to logistics, safety issues and the difficulty of landing and living on Dundas Island, females from Dundas Island only had satellite tags attached for one to two foraging trips to allow the tags to be recovered. In contrast, Enderby Island females had satellite tags attached for up to a month (Chilvers et al. 2005). Female NZ sea lions observed to be suckling a pup were captured using a specially designed hoop net and were physically restrained by two handlers. They were then anaesthetized, using isoflurane delivered with oxygen to a mask via a field-portable vaporizer (this methodology has been routinely applied to pinnipeds and to over 1,000 NZ sea lions; Gales and Mattlin 1998; Costa and Gales 2000; Childerhouse et al. 2004; Chilvers et al. 2005, 2006). Satellite-linked platform transmitting terminals (PTTS) (Telonics $300 \mathrm{~mW}$ ST6, potted in epoxy, $130 \times 35 \times 15 \mathrm{~mm}, 175 \mathrm{~g}$, Telonics Mesa, AZ, USA), VHF transmitters $(70 \times 30 \times 15 \mathrm{~mm}$, $25 \mathrm{~g}$, Sirtrack, Havelock North, New Zealand) and timedepth recorders (TDR) $(\mathrm{Mk} 9,40 \times 30 \times 22 \mathrm{~mm}, 30 \mathrm{~g}$ and $65 \times 18 \times 18 \mathrm{~mm}, 30 \mathrm{~g}$, Wildlife Computers, Redmond, WA, USA) were attached to a piece of neoprene material (Gales and Mattlin 1997), which was then glued to the females' dorsal hair just below shoulder level using twopart epoxy glue. Upon recapture, the instruments were removed by slicing through the width of the neoprene, eliminating the need to cut into the tag or the sea lion's hair. Once the instruments were secure $(8-10 \mathrm{~min}$ after glue application), the flow of anaesthetic was stopped and the animal was allowed to recover and return to her pup. Each animal was observed after restraint until they were fully conscious and had returned to the group or location where captured. Satellite tags were programmed to work continuously but were fitted with salt-water and wet-dry switches to ensure that transmission only occurred when animals were at sea.

Locations

\section{Individual comparisons}

Since NZ sea lions dive almost continuously while at sea (Gales and Mattlin 1997; Chilvers et al. 2006), all trips and satellite locations were assumed to be part of a foraging trip and to represent foraging locations. At sea, locations were provided by Argos (CLS Toulouse France), which provides six location qualities. All locations were filtered using the iterative forward/backward speed averaging filter that removes locations requiring swimming speeds greater than $2 \mathrm{~ms}^{-1}$ (McConnell et al. 1992; Crocker et al. 2001; Chilvers et al. 2005; Chilvers 2008b). Filtered locations were used to estimate distance from Dundas or Enderby Island and distance travelled. Total distance travelled was calculated by the linear interpolation of all filtered locations. Given the errors associated with satellite locations, all distance calculations are presented to the nearest $\mathrm{km}$ and the measure, total distance travelled, needs to be interpreted with possible accumulative affect of errors taken into consideration. Filtered locations were also used for the individual female kernel density plots of home ranges (Worton 1989) for 50 and 65\% of all locations per animal were determined using the Animal Movement Extension of ARCVIEW (Hooge et al. 2000). These provide two figures that represent the concentrated foraging range of a female NZ sea lion and thus likely the areas where foraging occurred (Chilvers et al. 2005). These figures were calculated using smoothing factors calculated via least-square cross-validation (Seaman and Powell 1996). One female's kernel range could not be calculated due to a low number of estimated locations.

\section{Colony comparisons}

Data for the foraging areas of the two breeding islands and all females combined weighted by colony size (Figs. 2, 3, 4 , respectively) were filtered separately using a speedbased algorithm from the IKNOS toolbox (custom software developed by Y. Tremblay). The algorithm uses several criteria to remove unlikely locations: (1) realistic travel speeds of a subject between 2 fixes, (2) change in azimuth between successive fixes, (3) Argos location class and (4) time lapse between 2 consecutive fixes. These data were then interpolated to obtain regular spaced locations. The kernel approach utilized was fixed kernel. A grid cell of $2 \times 2 \mathrm{~km}$ was used. The approach utilized to calculate Utilization Distributions introduces a correction to the typical kernel distribution approach, by correcting the data in terms of effort per area (in this case, $4 \mathrm{~km}^{2}$ ). The approach calculates a grid of the number of locations per day per grid cell and the number of animals tracked per grid cell. By dividing these, we obtained a grid with the normalized time spent by individuals per unit area, and we make the different tracks comparable (in terms of time) and correct for sampling bias (i.e. more individuals utilizing the area around the tagging site) and for colony size; Dundas Island colony has approximately four times the number of 
Fig. 2 Utilization distributions of 29 lactating NZ sea lions from Dundas Island during January and February of the austral summers 2005-2007. Utilization distributions are represented as highest concentration of locations $(25 \%$ of all location-darkest colour) through to lowest concentration (lightest colour). Auckland Island is represented in grey with thin black outline.

Bathymetric contours are shown as black lines. Auckland Island Shelf is represented by $500-\mathrm{m}$ bathymetric boundary

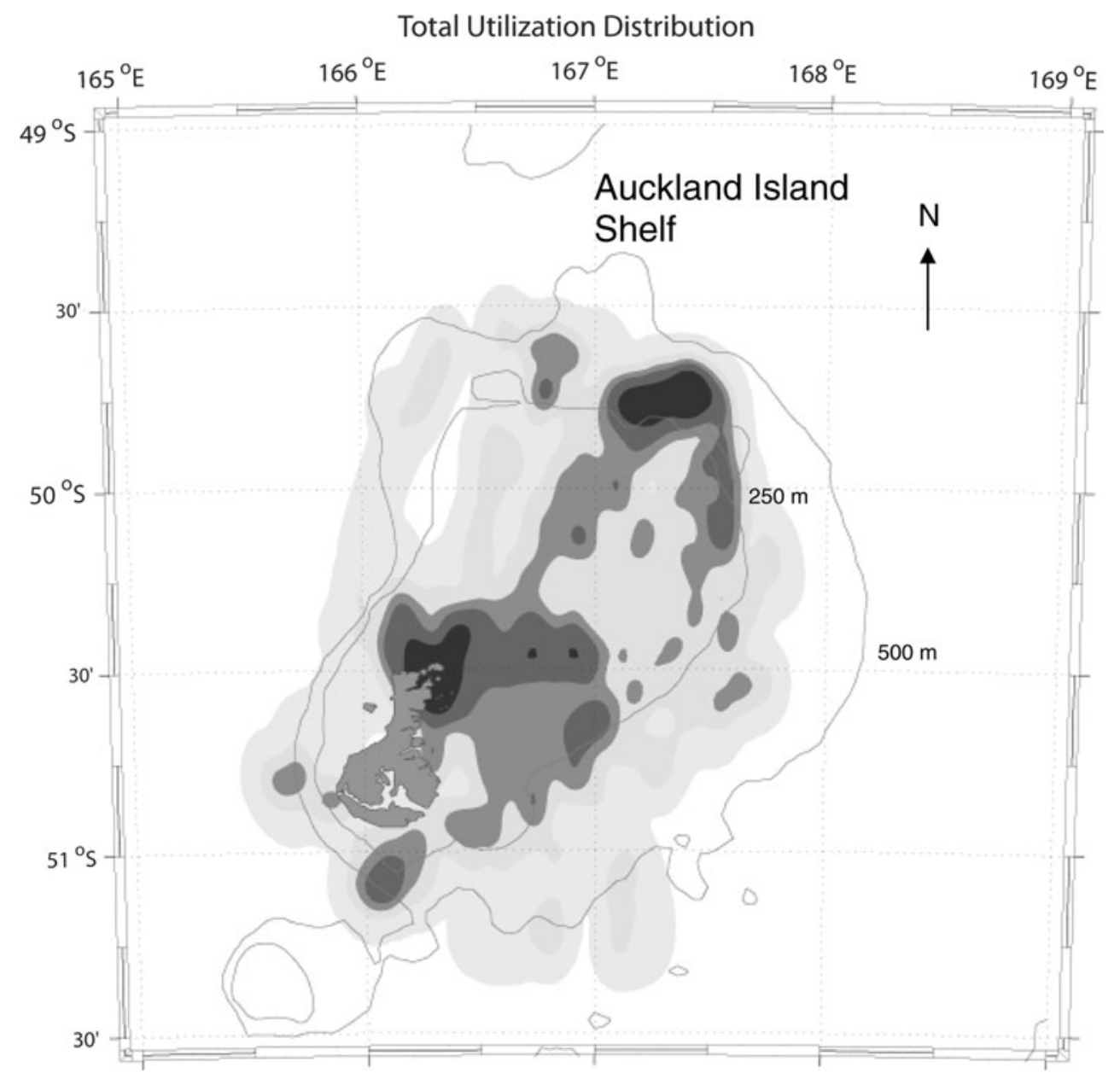

female NZ sea lions foraging from it than Enderby Island (Chilvers et al. 2007). A similar technique is used by Villegas-Amtmann et al. (2008) and Walli et al. (2009).

\section{Analysis}

All trip variables derived from location data were analysed using Excel, SPSS and ARCVIEW (Microsoft Office Excel 2003, ARCVIEW ${ }^{\odot} 1998$ ESRI inc., Redlands, California, SPSS 2004). Individual variation and variation in trip variables between breeding islands were analysed using one-way ANOVAs. The arrow squid fishery operational locations data and sea lion bycatch data were supplied by the Research Data Management section of the Ministry of Fisheries, New Zealand. Fisheries data represent all start/ stop locations for trawl shoots undertaken between 2001 and 2007. Kernel ranges representing 50 and $95 \%$ of all trawler activity were determined to show areas of highest activity. These figures using 50 and $95 \%$ were calculated in the same way as the individual foraging areas (outlined above).

\section{Results}

Dundas Island

Twenty-nine females from Dundas Island yielded 1,743 filtered locations, with equipment deployed or active for 2-64 days for each female. There were 41 complete foraging trips identified lasting 2-8 days. Deployment year, number of days deployed, foraging trip distances, kernel range (KR) sizes and straight line distances from the colony to the centre of foraging areas are shown in Table 1.

Foraging distances of individuals from Dundas Island were highly variable (range $=92-564 \mathrm{~km}$ ). Kernel range sizes also showed high variability between individuals, with mean areas of $691 \pm 84.2 \mathrm{~km}^{2}$ for $50 \% \mathrm{KR}$ and $1,213 \pm 139.2 \mathrm{~km}^{2}$ for $65 \% \mathrm{KR}$ (Table 1). Some females showed concentrated use of foraging areas $(n=8,50 \%$ $\mathrm{KR}<200 \mathrm{~km}^{2}$ ), while other females had diverse foraging areas $\left(n=13,50 \% \mathrm{KR}>800 \mathrm{~km}^{2}\right)$ (Table 1$)$. The mean distance from colony to the centre of females $50 \% \mathrm{KR}$ was $74 \pm 5.2 \mathrm{~km}$. Six females travelled $>99 \mathrm{~km}$ to reach the 
Fig. 3 Utilization distributions of 26 lactating NZ sea lions from Enderby Island during January and February of the austral summers 2001-2004. Utilization distributions are represented as highest concentration of locations $(25 \%$ of all locations-darkest colour) through to lowest concentration (lightest colour). Auckland Island is represented in grey. Bathymetric contours are shown as black lines. Auckland Island Shelf is represented by $500-\mathrm{m}$ bathymetric boundary

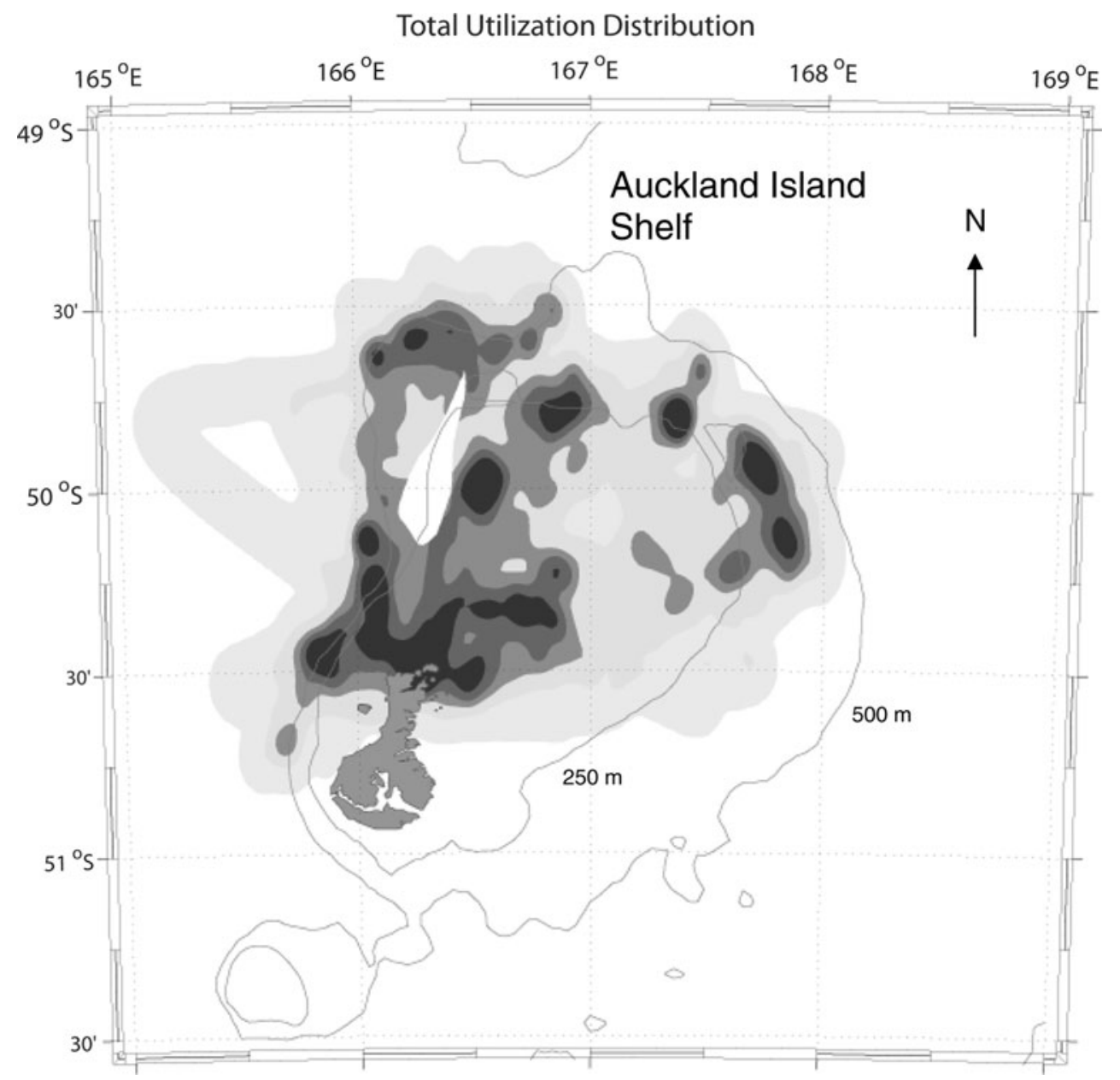

centre of their foraging area, while four females travelled $<35 \mathrm{~km}$. Since only one foraging trip was analysed for each individual, individual variation was not analysed.

Examination of areas used during foraging trips showed that Dundas Island breeding females principally forage in areas from north-east of the Auckland Island shelf to southwest of the continental shelf within the limits of the Auckland Rise (Fig. 2). However, there was considerable individual variation in their foraging areas and directions (Fig. 2). There are three distinct concentrations of female foraging locations: (1) north/north-east of Dundas Island, with a mean distance of $80-109 \mathrm{~km}$ from Dundas Island to KR (11 of the 29 females); (2) east of Dundas Islands, with a mean distance of $50-80 \mathrm{~km}$ from Dundas Island to KR (9 of the 29 females); and (3) the area south and south-east of Dundas Island and the main Auckland Island, with a mean distance of $20-50 \mathrm{~km}$ from Dundas Island to KR (9 of the 29 females) (Fig. 2).

\section{Enderby Island}

For comparison, here is a short summary of the Chilvers et al. (2005) data from the twenty-six females from Enderby
Island. Satellite tag deployment yielded 9,200 filtered locations, with equipment deployed or active for 5-36 days for each female. There were 183 complete foraging trips identified. Foraging distances of individuals from Enderby Island were highly variable (range $=58-901 \mathrm{~km}$ ). Kernel range sizes were highly variable between individuals, with mean areas of $378 \pm 80.5 \mathrm{~km}^{2}$ for $50 \% \mathrm{KR}$ and $643 \pm 131.1 \mathrm{~km}^{2}$ for $65 \% \mathrm{KR}$ (Table 1). The mean distance from colony to the centre of females $50 \% \mathrm{KR}$ was $64 \pm 6.5 \mathrm{~km}$. Six females travelled $>99 \mathrm{~km}$ to reach the centre of their foraging area, while ten females travelled $<35 \mathrm{~km}$. Enderby Island breeding females principally forage in areas north and north-east of the Enderby Island Auckland Island (Fig. 3).

\section{Comparison between Dundas and Enderby Island female foraging}

The only significant difference when comparing Dundas and Enderby Islands females foraging parameters (Table 1; Chilvers et al. 2005) was "total trip distance". Enderby Island females travelled on average further within a foraging trip than Dundas Island females (Dundas Island mean 
Fig. 4 Utilization distributions of all filtered satellite locations for 55 lactating NZ sea lions from Enderby and Dundas Islands weighed by colony size during January and February of the austral summers 2001-2007 and squid trawl fishery effort (50 and $95 \%$ kernel ranges 2001-2007, represented as thick black lines). NZ sea lion utilization distributions are represented as highest concentration of locations ( $25 \%$ of all locations-darkest colour) through to lowest concentration (lightest colour). Auckland Island is represented in grey. Bathymetric contours are shown as thin black lines. Auckland Island Shelf is represented by 500-m bathymetric boundary

\section{Total Utilization Distribution}

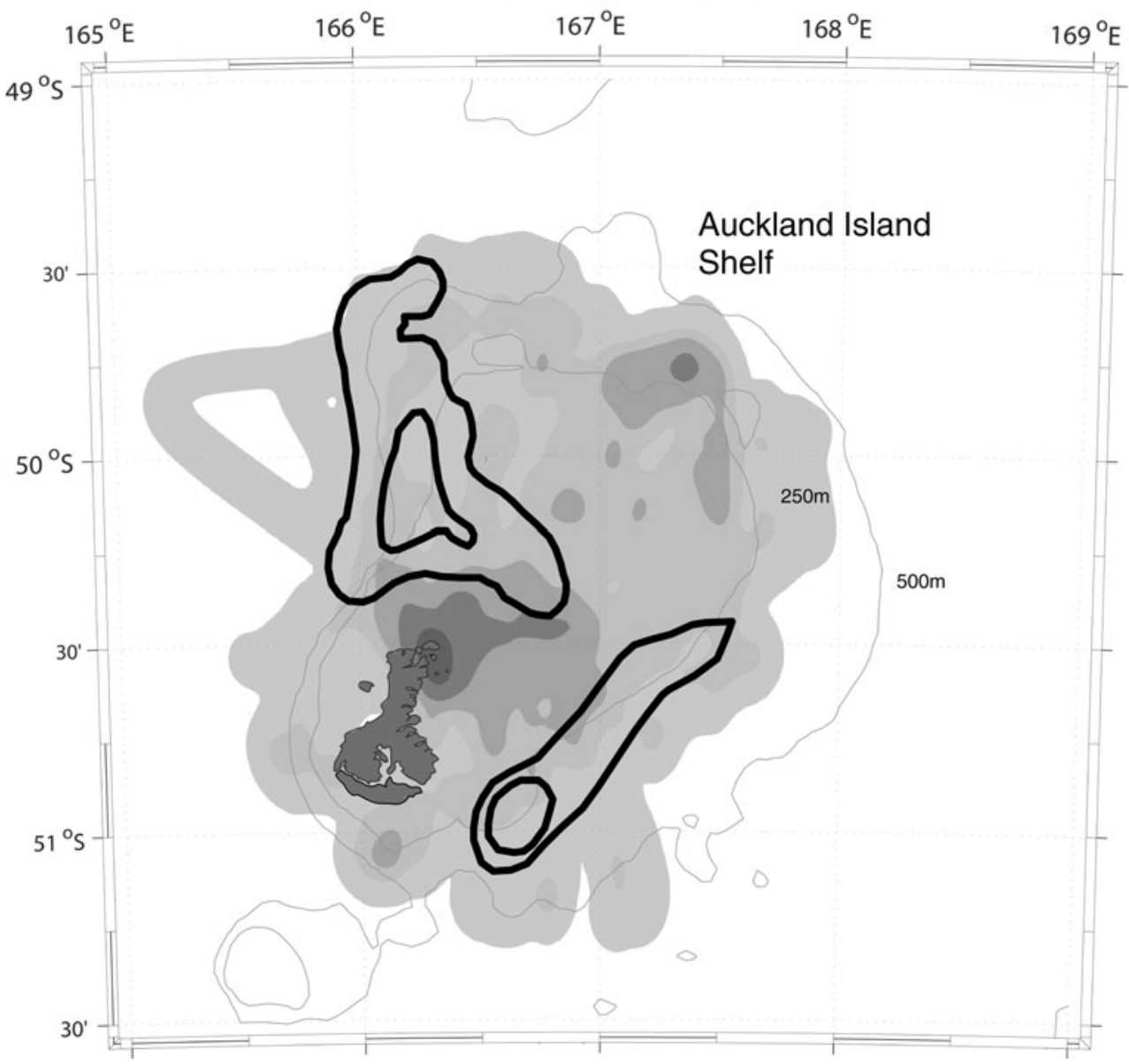

$302 \mathrm{~km} \pm 21.5$, Enderby Island $423 \mathrm{~km} \pm 43.9, F_{[1,54]}=$ $6.1, P=0.016)$. This greater total trip distance correlates with the greater maximum distances from breeding islands Enderby Island females travel than for Dundas Island females (Table 1; Dundas Island mean $87 \mathrm{~km} \pm 5.3$, Enderby Island $102 \pm 7.7)$.

There were no significant differences between KR sizes between breeding islands. As Enderby Islands females KR were means from multiple foraging trip whereas Dundas Island females KR were from single foraging trips, a single foraging trip was randomly selected from Enderby Island females to establish a KR, and these were compared with Dundas Island females.

Although there is overlap between the Enderby and Dundas Island female foraging areas in the north-east of the Auckland Island shelf, there are two distinct foraging areas where the females from each breeding island do not overlap (Figs. 2, 3): the area north-west of Enderby Island, where only Enderby Island females occur (Fig. 3), and the area south and south-east of Dundas Island, where only Dundas Island females are found (Fig. 2).
Fishery interactions

There is extensive overlap between lactating female NZ sea lion foraging locations from both breeding islands and fishery operations. Figure 4 shows the area utilization of female NZ sea lion weighed by colony size and squid fisheries effort kernels calculated from trawl start/stop locations from 2001 to 2007. Although the number of trawls undertaken by the fishery varies between years, there is little variation in the areas fished (Chilvers et al. 2005; Chilvers 2008a). Seventy per cent of all sea lion bycatch mortality occurs within the $50 \% \mathrm{KR}$ of fishery effort (Chilvers et al. 2005), and two fishing areas predominate: one lies south-east of the Auckland Islands along the 250-m bathymetry line (44\% of all tows undertaken between 2001 and 2004) and the second is north/north-west of the Auckland Islands (56\% of all tows undertaken between 2001 and 2004).

Enderby Island females that forage directly north and west of Enderby Island have significant overlap with the north-west fishery operations. Nine of the 26 Enderby 
Table 1 Deployment year, number of days deployed, foraging trip distances, kernel range (KR) sizes and mean straight line distances from colony to centre of foraging trips for 29 New Zealand sea lions from Dundas Island, Auckland Islands

\begin{tabular}{|c|c|c|c|c|c|c|c|c|c|}
\hline $\begin{array}{l}\text { Year }^{\mathrm{a}} \\
\text { deployed }\end{array}$ & ID & $\begin{array}{l}\text { No. days } \\
\text { deployed }\end{array}$ & $\begin{array}{l}\text { Total no. } \\
\text { locations }\end{array}$ & $\begin{array}{l}\text { No. of } \\
\text { trips }\end{array}$ & $\begin{array}{l}\text { Trip distance }{ }^{b} \\
(\mathrm{~km})\end{array}$ & $\begin{array}{l}\text { Max. distance } \\
\text { from colony }(\mathrm{km})\end{array}$ & $\begin{array}{l}50 \% \mathrm{KR} \\
\left(\mathrm{km}^{2}\right)\end{array}$ & $\begin{array}{l}65 \% \mathrm{KR} \\
\left(\mathrm{km}^{2}\right)\end{array}$ & $\begin{array}{l}\text { Mean distance from } \\
\text { colony to centre } \\
\text { of } \mathrm{KR}(\mathrm{km})\end{array}$ \\
\hline 2005 & 1 & 4 & 30 & 1 & 308 & 111 & 1,038 & 1,585 & 99 \\
\hline 2005 & 2 & 64 & 495 & 8 & $354 \pm 21.1$ & 114 & 722 & 1,052 & 109 \\
\hline 2005 & 3 & 4 & 21 & 1 & 282 & 44 & 183 & 535 & 33 \\
\hline 2005 & 4 & 3 & 16 & 1 & 92 & 24 & 38 & 130 & 21 \\
\hline 2005 & 5 & 3 & 16 & 1 & 508 & 116 & 1,316 & 2,687 & 95 \\
\hline 2005 & 6 & 6 & 104 & 2 & $307 \pm 21.6$ & 101 & 1,614 & 2,075 & 73 \\
\hline 2005 & 7 & 5 & 54 & 1 & 399 & 114 & 713 & 1,115 & 109 \\
\hline 2005 & 8 & 2 & 10 & 1 & 150 & 67 & 198 & 365 & 64 \\
\hline 2005 & 9 & 3 & 32 & 1 & 220 & 97 & 1,003 & 1,990 & 80 \\
\hline 2006 & 1 & 4 & 19 & 1 & 281 & 126 & 86 & 236 & 122 \\
\hline 2006 & 2 & 4 & 34 & 1 & 398 & 109 & 978 & 1,830 & 101 \\
\hline 2006 & 3 & 3 & 10 & 1 & 280 & 70 & n.a. & n.a. & n.a. \\
\hline 2006 & 4 & 4 & 44 & 1 & 148 & 48 & 369 & 608 & 43 \\
\hline 2006 & 5 & 6 & 43 & 1 & 384 & 95 & 953 & 1,491 & 86 \\
\hline 2006 & 6 & 6 & 128 & 2 & $564 \pm 35.6$ & 104 & 1,330 & 1,960 & 71 \\
\hline 2006 & 7 & 3 & 42 & 1 & 286 & 103 & 1,140 & 1,850 & 88 \\
\hline 2006 & 8 & 7 & 61 & 2 & $354 \pm 53.8$ & 92 & 904 & 1,480 & 75 \\
\hline 2006 & 9 & 8 & 170 & 3 & $493 \pm 63.2$ & 84 & 235 & 473 & 55 \\
\hline 2006 & 10 & 5 & 33 & 1 & 150 & 27 & 44 & 84 & 22 \\
\hline 2007 & 1 & 4 & 20 & 1 & 135 & 49 & 197 & 543 & 38 \\
\hline 2007 & 2 & 4 & 32 & 1 & 257 & 108 & 990 & 2,431 & 99 \\
\hline 2007 & 3 & 4 & 21 & 1 & 287 & 111 & 1,058 & 1,824 & 89 \\
\hline 2007 & 4 & 4 & 28 & 1 & 193 & 57 & 286 & 579 & 52 \\
\hline 2007 & 5 & 3 & 31 & 1 & 285 & 82 & 741 & 1,498 & 79 \\
\hline 2007 & 6 & 5 & 49 & 1 & 292 & 100 & 958 & 1,635 & 92 \\
\hline 2007 & 7 & 4 & 43 & 1 & 408 & 102 & 961 & 1,544 & 74 \\
\hline 2007 & 8 & 8 & 72 & 1 & 410 & 56 & 181 & 378 & 34 \\
\hline 2007 & 9 & 4 & 59 & 1 & 340 & 112 & 612 & 1,234 & 88 \\
\hline 2007 & 10 & 3 & 26 & 1 & 214 & 99 & 520 & 772 & 94 \\
\hline \multicolumn{5}{|c|}{ Dundas means } & $302 \pm 21.5$ & $87 \pm 5.3$ & $691 \pm 84.2$ & $1,213 \pm 139.2$ & $74 \pm 5.2$ \\
\hline \multicolumn{5}{|c|}{ Enderby means ${ }^{\mathrm{c}}$} & $423 \pm 43.9$ & $102 \pm 7.7$ & $378 \pm 80.5$ & $643 \pm 131.1$ & $64 \pm 6.5$ \\
\hline
\end{tabular}

Means presented $\pm \mathrm{SE}$

${ }^{a}$ Instrument deployment between 12 January and 18 February within each year

${ }^{b}$ For animals that made more than one trip, trip distance is shown as mean trip distance $\pm \mathrm{SE}$

${ }^{c}$ Enderby means from Chilvers et al. 2005

Island females tracked forage in this area, and $72 \%$ of all fishery bycatch captures of sea lions are reported in this area (Chilvers et al. 2005). There is no apparent overlap between Enderby Island females and the south-east part of the fishery. Instead, it is the Dundas Island females that forage east to south-east of the island that overlap with the south-east fishery area. Nine of the 29 females tracked forage in this area, in which $28 \%$ of all bycatch occurs. It should be noted that bycatch data are dependent on observers and the fishery reporting their occurrence; therefore, there may be bias in the data if observer coverage varies significantly between the two fishing areas and/ or fishery neglect to report captures.

\section{Discussion}

This is the first research to investigate and compare the foraging areas of lactating female NZ sea lions from the species two largest breeding islands and to compare 
foraging area overlap with fisheries interactions. Females from the two breeding islands show the same high individual variability in foraging locations (Here; Chilvers et al. 2005); however, together they forage over the entire Auckland Island shelf and edges and forage in areas of high fishery use and bycatch (Fig. 4).

Colony-specific foraging areas have been documented for Antarctic fur seals (Boyd et al. 2002) and specific foraging areas from breeding sites on the same islands for Northern fur seals (Robson et al. 2004). Dundas and Enderby Island females do not show entirely distinct colony-specific foraging areas, as there is a large overlap in area and the number of females that forage in the north/ north-east part of the Auckland Island shelf. This overlap may reflect a higher productivity or greater reliability of prey within this area allowing this number of animals to be sustained, or may indicate limited resource availability or resource competition with the main fisheries areas in other areas forcing individuals of different colonies to forage in the same area. Support for limited prey availability comes from Bradford-Grieve et al. (2003) who have shown that the Auckland Island rise is an iron-limited low productivity area with low levels of phytoplankton biomass and primary production. They calculated that commercial fishing accounted for $32 \%$ of the total biomass taken from this low productivity area, while top predators, which include sea lions, fur seals, sea birds and toothed and baleen cetaceans, only took $17 \%$. Lactating NZ sea lions have also been shown to have foraging/diving behaviours that are at their physiological limits, with $68 \%$ of all of their dives being beyond their calculated anaerobic dive limits (Costa and Gales 2000; Chilvers et al. 2006). This extreme diving appears to be reflected in the reproductive ability of this species with NZ sea lions showing the lowest female reproductive rate of any Otariid (Chilvers et al. 2010). Interestingly, no squid trawling occurs in the area north/ north-east on the Auckland Island shelf, where the greatest overlap between the foraging distributions of animals from the two breeding islands is greatest, indicating low squid abundance and supporting diet studies showing that squid is not found in all individuals' diets (Meynier et al. 2009).

Recently, Enderby Island lactating NZ sea lions have been shown to have two distinct dive profile types: a benthic diving profile and a deeper, more varied mesopelagic diving profile (Chilvers 2008a; Chilvers and Wilkinson 2008). Females with these different profiles have significantly different dive parameters, foraging locations, associated energetic costs and prey choice (Chilvers and Wilkinson 2008). In turn, these variations may lead to differences in the survival of individuals and interactions with fishery and influence colony demographics (Chilvers 2008a; Chilvers and Wilkinson 2008). Parallel investigations are currently being undertaken for Dundas Island females.

The identification of foraging habitat and partitioning of resources between the females from breeding islands allows us to understand how breeding females' foraging areas overlap within the species and with squid trawl fishery activities. Using the technique of utilization distributions allows numerous animal satellite data to be normalized in terms of effort per area including by the number of animals tracked per grid cell, correcting for sampling bias (i.e. more individuals utilizing the area around the tagging site) and for colony size. This information could also allow the development of effective marine protected area (MPA) management options for the conservation of NZ sea lions. Protection of a species needs to focus on the most vulnerable and restricted proportion of the species (Hooker and Gerber 2004), which, for NZ sea lions, is the Auckland Island area, where $86 \%$ of the entire species breeds and where breeding lactating females are obligated to forage within the area to survive and rear their young. Effective marine protection needs to cover both the on-land breeding areas and the essential food resources surrounding them. Foraging studies have shown that the current 12-n.m. $(22 \mathrm{~km})$ MPA surrounding the Auckland Islands does not provide protection of the entire foraging area for any of the lactating females tracked from Enderby Island and only one female from Dundas Island (Here, Chilvers et al. 2005). To protect the entire foraging ranges of the 55 female NZ sea lions from both Enderby and Dundas Islands, an MPA would need to be extensive over the Auckland Island shelf. This protection could be established through the extension of the current Marine Mammal Sanctuary or though closure of the fishery area through the Fishery Act (1996). Alternatively, the restriction of fishing methods to squid jigging over the Auckland Island shelf would result in an estimated zero sea lion bycatch rate, while still allowing fishing within the area (Sauer 1995; Arnould et al. 2003; Chilvers 2008a). Marine protected area fishery management has been implemented and has shown positive results for Steller sea lions in Alaska (Hennen 2006).

Acknowledgments These data were collected under funding from the New Zealand Department of Conservation (DOC-Investigation no. 1638) in parallel with field work undertaken for DOC Conservation Services Programme (www.csp.org.nz) project POP2006/01. DOC Southland are thanked for their logistical assistance. We also thank M. Blake, M. Brown, S. Childerhouse, J. Fyfe, K. Geschke, R. Hood, L. Meyner and K. Morgan for assistance with captures in the field. Thanks also to C. Edkins for graphics help. Approval for work was obtained from DOC Animal Ethics Committee-Approval AEC86 (1 July 1999). I. West and A. Todd provided helpful, critical reviews of the manuscript. We thank the Research Data Management section of the Ministry of Fisheries, New Zealand, for the arrow squid fishery operational locations data and sea lion bycatch data. 
Open Access This article is distributed under the terms of the Creative Commons Attribution Noncommercial License which permits any noncommercial use, distribution, and reproduction in any medium, provided the original author(s) and source are credited.

\section{References}

Arnould JPY (1997) Lactation and the cost of pup rearing in Antarctic fur seals. Mar Mamm Sci 13:516-526

Arnould JPY, Trinder DM, McKinley CP (2003) Interactions between fur seals and a squid jig fishery in southern Australia. Mar Freshw Res 54:979-984

Baird SJ (1996) Non fish species and fisheries interactions working groups report. May 1996. New Zealand fisheries assessment working group report 96/1. Ministry of Fisheries, Wellington

Baker CS, Chilvers BL, Constantine R, DuFresne S, Mattlin R, van Helden A, Hitchmough R (2010) Conservation status of New Zealand marine mammals (suborders Cetacea and Pinnipedia), 2009. NZ J Mar Freshw Res 44:101-115

Boyd IL, Staniland IJ, Martin AR (2002) Distribution of foraging by female Antarctic fur seals. MEPS 242:285-294

Bradford-Grieve JM, Probert PK, Nodder SD, Thompson D, Hall J, Hanchet S, Boyd P, Zeldis J, Baker AN, Best HA (2003) Pilot trophic model for subantarctic water over the Southern Plateau, New Zealand: a low biomass, high transfer efficiency system. J Exp Mar Biol Ecol 289:223-262

Campbell RA, Chilvers BL, Childerhouse S, Gales NJ (2006) Conservation management issues and status of the New Zealand (Phocarctos hookeri) and Australian (Neophoca cinerea) sea lions. In: Trites AW, DeMaster DP, Fritz LW, Gelatt LD, Rea LD, Wynne KM (eds) Sea lions of the world. Lowell Wakefield Fisheries Symposium, University of Alaska, Fairbanks, pp 455-471

Childerhouse S, Dix B, Gales NJ (2001) Diet of New Zealand sea lions (Phocarctos hookeri) at the Auckland islands. Wildl Res 28:291-298

Childerhouse S, Dickie G, Hessel G (2004) Ageing live New Zealand sea lions (Phocarctos hookeri) using the first post-canine tooth. Wildl Res 31:177-181

Chilvers BL (2008a) New Zealand sea lions (Phocarctos hookeri) and squid trawl fisheries: bycatch problems and management options. Endanger Species Res 5:193-204

Chilvers BL (2008b) Foraging site fidelity of lactating New Zealand sea lions. J Zool (Lond) 276:28-36

Chilvers BL, Wilkinson IS (2008) Philopatry and site fidelity of New Zealand sea lions, Phocarctos hookeri. Wildl Res 35:463-470

Chilvers BL, Wilkinson IS (2009) Divers foraging strategies in lactating New Zealand sea lions. MEPS 378:299-308

Chilvers BL, Wilkinson IS, Duignan PJ, Gemmell NJ (2005) Identifying the distribution of summer foraging areas for lactating New Zealand sea lions, Phocarctos hookeri. MEPS 304:235-247

Chilvers BL, Wilkinson IS, Duignan PJ, Gemmell N (2006) Diving to extremes: are New Zealand sea lions (Phocarctos hookeri) pushing their limits in a marginal habitat? J Zool (Lond) 269:233-241

Chilvers BL, Wilkinson IS, Childerhouse S (2007) New Zealand sea lion, Phocarctos hookeri, pup production-1995 to 2005. NZ J Mar Freshw Res 41:205-213

Chilvers BL, Wilkinson IS, McKenzie D (2010) Predicting life-history traits for female New Zealand sea lions, Phocarctos hookeri: integrating short-term mark-recapture data and population modelling. J Agric Biol Environ Stat 15:259-264
Costa DP (1991a) Reproductive and foraging energetics of high latitude penguins, albatross and pinnipeds: implications for life history patterns. Am Zool 31:111-130

Costa DP (1991b) Reproductive and foraging energetics of pinnipeds: implications for life history patterns. In: Renouf D (ed) Behaviour of pinnipeds. Chapman and Hall, London, pp 300-344

Costa DP (1993) The relationship between reproductive and foraging energetics and the evolution of the pinnipedia. In: Boyd I (ed) Marine mammals: advances in behavioural and population biology. Symposia of the zoological society of London, vol 66 . Oxford University Press, Oxford, pp 293-314

Costa DP (2007) A conceptual model of the variation in parental attendance in response to environmental fluctuation: foraging energetics of lactating sea lions and fur seals. Aquat Conserv Mar Freshw Ecosyst 17:S44-S52

Costa DP, Gales NJ (2000) Foraging energetic and diving behaviour of lactating New Zealand sea lions, Phocarctos hookeri. J Exp Biol 203:3655-3665

Crocker DE, Gales NJ, Costa DP (2001) Swimming speed and foraging strategies of New Zealand sea lions (Phocarctos hookeri). J Zool (Lond) 254:267-277

Gales NJ, Mattlin RH (1997) Summer diving behaviour of lactating New Zealand sea lions, Phocarctos hookeri. Can J Zool 75:1695-1706

Gales NJ, Mattlin RH (1998) Fast, safe, field-portable gas anesthesia for pinnipeds. Mar Mamm Sci 14:355-361

Geschke K, Chilvers BL (2009) Managing big boys: a case study on remote anaesthesia and satellite tracking of adult male New Zealand sea lions (Phocarctos hookeri). J Wildl Res 36:666-674

Gittleman JL, Thompson SD (1988) Energy allocation in mammalian reproduction. Am Zool 28:863-875

Hennen D (2006) Associations between the Alaska Steller sea lion decline and commercial fisheries. Ecol Appl 16:704-717

Hooge PN, Eichenlaub WM, Solomon EK (2000) Using GIS to analyse animals movements in the marine environment. Alaska Biological Science Centre. US Geological Survey, Gustavus

Hooker SA, Gerber LR (2004) Marine reserves as a tool for ecosystem-based management: the potential importance of megafauna. Bioscience 54:27-39

Hunt GL Jr, Harrison NM, Cooney RT (1990) The influence of hydrographic structure and prey abundance on foraging of least auklets. Stud Avian Biol 14:7-22

McConnell BJ, Chambers C, Fedak MA (1992) Foraging ecology of southern elephant seals in relation to the bathymetry and productivity of the southern oceans. Antarct Sci 4:393-398

Meynier L, MacKenzie DDS, Duignan PJ, Chilvers BL, Morel PCH (2009) Variability in the diet of New Zealand sea lion (Phocarctos hookeri) at the Auckland islands, New Zealand. Mari Mamm Sci 25:302-326

Robertson GG (1994) The foraging ecology of emperor penguins (Aptenodytes forsteri) at two Mawson Coast colonies, Antarctica. Ph.D. Dissertation, University of Tasmania

Robertson BC, Chilvers BL, Duignan PJ, Wilkinson IS, Gemmell NJ (2006) Dispersal of breeding, adult male Phocarctos hookeri: implications for disease transmission, population management and species recovery. Bio Cons 127:227-236

Robson BW, Goebel ME, Baker JD, Ream RR, Loughlin TR, Francis RC, Antonelis GA, Costa DP (2004) Separation of foraging habitat among breeding sites of a colonial marine predator, the northern fur seal (Callorhinus ursinus). Can J Zool 82:20-29

Sauer WHH (1995) The impact of fishing on chokka squid, Loligo vulgaris reynaudii, concentrations on inshore spawning grounds in the south-eastern cape, South Africa. S Afr J Mai Sci 16:185-193

Seaman DE, Powell RA (1996) An evaluation of the accuracy of kernel density estimators for home range analysis. Ecology 77:2075-2085 
Trillmich F, Weissing FJ (2006) Lactation patterns of pinnipeds are not explained by optimization of maternal energy delivery rates. Behav Ecol Sociobiol 59:1-13

Twiss JR Jr, Reeves RR (1999) Conservation and management of marine mammals. Smithsonian Institution Press, Washington, USA

Uozumi Y (1998) Fishery biology of arrow squids, Nototodarus gouldi, and N. sloanii, in New Zealand waters. Bul Nat Res Inst Far Seas Fisher 35:1-111

Villegas-Amtmann S, Costa DP, Tremblay Y, Salazar S, AuriolesGamboa D (2008) Multiple foraging strategies in a marine apex predator, the Galapagos sea lion, Zalophus wollebaeki. MEPS 363:299-309

Walli A, Teo SLH, Boustany A, Farwell CJ, Williams T, Dewar H, Prince E, Block BA (2009) Seasonal movements, aggregations and diving behaviour of Atlantic bluefin tuna (Thunnus thynnus) revealed with archival tags. http://www.plosone.org/article/ info\%3Adoi\%2F10.1371\%2Fjournal.pone.0006151

Weimerskirch H (1998) How can a pelagic seabird provision its chick when relying on a distant food resource? Cyclic attendance at the colony, foraging decision and body condition in sooty shearwaters. J Anim Ecol 67:99-109

Wilkinson IS, Burgess J, Cawthorn MW (2003) New Zealand sea lions and squid-managing fisheries impacts on a threatened marine mammal. In: Gales N, Hindell M, Kirkwood R (eds) Marine mammals: fisheries, tourism and management. CSIRO Publishing, Melbourne, pp 92-207

Worton BJ (1989) Kernel methods for estimating the utilization distribution in home-range studies. Ecology 70:164-168 